\begin{tabular}{|l|l|l|}
\hline \multicolumn{2}{|c|}{ PublisherInfo } \\
\hline \hline PublisherName & $:$ & BioMed Central \\
\hline \hline PublisherLocation & $:$ & London \\
\hline \hline PublisherImprintName & $:$ & BioMed Central \\
\hline \hline
\end{tabular}

\title{
Noninvasive ventilation after lung resection
}

\begin{tabular}{|c|c|c|}
\hline \multicolumn{3}{|c|}{ ArticleInfo } \\
\hline ArticleID & $:$ & 4320 \\
\hline ArticleDOI & $:$ & $10.1186 /$ ccf-2001-73650 \\
\hline ArticleCitationID & $:$ & 73650 \\
\hline ArticleSequenceNumber & $:$ & 31 \\
\hline ArticleCategory & : & Paper Report \\
\hline ArticleFirstPage & : & 1 \\
\hline ArticleLastPage & : & 4 \\
\hline ArticleHistory & : & $\begin{array}{ll}\text { RegistrationDate } & : 2001-12-6 \\
\text { Received } & : 2001-11-21 \\
\text { OnlineDate } & : 2001-12-6\end{array}$ \\
\hline ArticleCopyright & $:$ & Biomed Central Ltd2001 \\
\hline ArticleGrants & : & \\
\hline ArticleContext & : & 1305455 \\
\hline
\end{tabular}


Aff1 Mayo Clinic, Rochester, MN, USA

\section{Keywords}

Pneumonectomy, respiratory failure, ventilation

\section{Context}

When compared with the usual regime of oxygen supplementation, noninvasive positive pressure ventilation (NIPPV) has been shown to have a number of advantages: it can decrease the need for endotracheal intubation in unselected patients with acute respiratory failure (see Additional information [1]); in immunosuppressed patients it can decrease ICU mortality (see Additional information [2]); and in a small group of patients that had undergone lung resection it resulted in improved gas exchange without undesirable effects (see Additional information [3]). NIPPV should not be confused with continuous positive airway pressure, which has not been shown to be of benefit in patients with acute hypoxemic respiratory failure (see Additional information [4]). This study compares outcomes of either NIPPV or standard oxygen supplementation in patients who have undergone lung resection.

\section{Significant findings}

A total of 48 patients were prospectively enrolled ( 24 in each arm). The study was stopped prematurely because of a significant difference in the primary outcome measure, need for endotracheal intubation $(20.8 \%$ versus $50 \%, \mathrm{P}=0.035)$. The hospital mortality $(12.5 \%$ versus $37.5 \%, \mathrm{P}=0.045)$ and 120 -day mortality (12.5\% versus $37.5 \%)$ were lower in the NIPPV group. There was no significant difference in either the length of ICU $(\mathrm{P}=0.52)$ or hospital $(\mathrm{P}=0.61)$ stay.

\section{Comments}

This study supports the trend in current practice towards earlier use of NIPPV in patients with acute respiratory failure. The earlier decrease in the work of breathing and avoidance of complications associated with endotracheal intubation (e.g. infection, sedation, ventilator induced lung injury and 
barotrauma) are likely reasons for the observed decrease in mortality. As in other NIPPV studies, patients who experienced hemodynamic stability, excessive secretions, agitation, or extreme respiratory distress were excluded from the study.

\section{Methods}

Patients with acute hypoxemic respiratory failure after lung resection were randomized to usual care (oxygen, bronchodilators, chest physiotherapy) with or without NIPPV. The study was not blinded. The primary outcome was the need for endotracheal intubation. Secondary outcomes were hospital and 120-day mortality, and duration of hospital and ICU stay.

\section{Additional information}

1. Martin TJ, Hovis JD, Costantino JP, Bierman MI, Donahoe MP, Rogers RM, Kreit JW, Sciurba FC, Stiller RA, Sanders MH: A randomized, prospective evaluation of noninvasive ventilation for acute respiratory failure.

Am J Respir Crit Care Med 2000, 161:807-813.

2. Hilbert G, Gruson D, Vargas F, Valentino R, Gbikpi-Benissan G, Dupon M, Reiffers J, Cardinaud JP: Noninvasive ventilation in immunosuppressed patients with pulmonary infiltrates, fever, and acute respiratory failure.

N Engl J Med 2001, 344:481-487.

3. Aguilo R, Togores B, Pons S, Rubi M, Barbe F, Agusti AG. Noninvasive ventilatory support after lung resectional surgery.

Chest 1997, 112:117-121.

4. Delclaux C, L'Her E, Alberti C, Mancebo J, Abroug F, Conti G, Guerin C, Schortgen F, Lefort Y, Antonelli M, Lepage E, Lemaire F, Brochard L: Treatment of acute hypoxemic nonhypercapnic respiratory insufficiency with continuous positive airway pressure delivered by a face mask: A randomized controlled trial.

JAMA 2000, 284:2352-2360. 


\section{References}

1. Auriant I, Jallot A, Herve P, Cerrina J, Le Roy Ladurie F, Fournier JL, Lescot N, Parquin F:

Noninvasive ventilation reduces mortality in acute respiratory failure following lung resection. Am J Respir Crit Care Med . 2001, 164: 1231-1235. 